\title{
Carinoma hamanako sp. nov. (Nemertea: Palaeonemertea), the First Representative of the Genus from the Northwest Pacific
}

\author{
Hiroshi Kajihara ${ }^{1}$, Hiroshi Yamasaki ${ }^{2}$ and Sónia C. S. Andrade ${ }^{3}$ \\ ${ }^{1}$ Faculty of Science, Hokkaido University, Sapporo 060-0810, Japan \\ E-mail: kazi@mail.sci.hokudai.ac.jp \\ ${ }^{2}$ Graduate School of Science, Hokkaido University, Sapporo 060-0810, Japan \\ ${ }^{3}$ Museum of Comparative Zoology, Department of Organismic and Evolutionary Biology, \\ Harvard University, 26 Oxford Street, Cambridge, MA 02138, USA
}

(Received 21 January 2011; Accepted 20 April 2011)

\begin{abstract}
Carinoma hamanako sp. nov., the ninth member of the genus, is described based on three specimens collected in Lake Hamana, Shizuoka Prefecture, Pacific coast of Honshu, Japan. The new species can be distinguished from its congeners by the blind-ending rhynchocoelic villar vessels, the lateral rhynchocoel vessels rejoining the lateral vessels, the unbranched excretory canals, the situation of the posterior part of the mid-dorsal nerve within the longitudinal muscle layer of the body wall, and the absence of a vascular plexus in the foregut region. A phylogenetic analysis based on the nuclear 28S rRNA and mitochondrial cytochrome $c$ oxidase subunit I genes shows that $C$. hamanako sp. nov. forms a clade with two congeners, $C$. mutabile Griffin, 1898 and C. tremaphoros Thompson, 1900, thus supporting the generic placement of the new species.
\end{abstract}

Key Words: Nemertea, palaeonemertean, Japan, taxonomy, anatomical description, molecular phylogeny, new species.

\section{Introduction}

Palaeonemerteans, or Palaeonemertea s. lat., comprise a likely paraphyletic assemblage of basal clades within the phylum Nemertea, with one group, the hubrechtellids, being a sister group of the Heteronemertea, and the latter two together constituting a monophyletic Pilidiophora (Thollesson and Norenburg 2003). So far, 110 species in Palaeonemertea s. str., i.e. excluding the 15 species of Hubrechtellidae, are known worldwide (Gibson 1995; Kajihara 2006; Kajihara et al. 2008).

The palaeonemertean (s. lat.) fauna of Japanese waters has been studied by Takakura (1898, 1922), Yamaoka (1940), Iwata (1951, 1952, 1954a, b, 1957), Senz (1997), and Kajihara (2006); 14 species in seven genera are currently known, including hubrechtellids (reviewed by Kajihara 2007), but no member of the genus Carinoma Oudemans, 1885 has been reported from this region. In the present paper we describe a new species of Carinoma, the ninth member of the genus, representing the first record of Carinoma from the Northwest Pacific. In addition, its phylogenetic position is evaluated based on DNA sequence data from two molecular markers 
commonly used in phylogenetic studies, 28S ribosomal RNA (28S rRNA) and cytochrome $c$ oxidase subunit I (COI).

\section{Material and Methods}

Nemerteans were collected at ebb tide on 30 March 2009 from a sandy to muddy tidal flat on Ikarise Island, $34^{\circ} 41^{\prime} 04^{\prime \prime} \mathrm{N}, 137^{\circ} 35^{\prime} 59^{\prime \prime} \mathrm{E}$, located in the channel forming the outlet to the Pacific Ocean of Lake Hamana, Shizuoka Prefecture, Honshu, Japan. They were anaesthetized in a $\mathrm{MgCl}_{2}$ solution isotonic to seawater. The anterior half of each worm was fixed in $10 \%$ formalin seawater for 24 hours and preserved in $70 \%$ EtOH for morphological observation; the posterior halves were fixed and preserved in RNAlater $®$ (Ambion, Inc., Austin, Texas, USA) for nucleotide extraction. The anterior halves were dehydrated in $100 \% \mathrm{EtOH}$, cleared in xylene, and embedded in paraffin wax (m.p. $56-57^{\circ} \mathrm{C}$ ) before being sectioned at $8 \mu \mathrm{m}$ thickness. Sections were stained by the Mallory trichrome method (Gibson 1994). The description of morphological characters and their states is largely based on Sundberg et al. (2009). The slides of the type series are deposited in the Hokkaido University Museum, Sapporo, Japan (ZIHU).

Total genomic DNA was extracted from the posterior halves of the specimens, using the DNeasy kit (Qiagen, Inc., Valencia, California, USA) according to the manufacturer's protocol. A fragment of the 5 ' end of $28 \mathrm{~S}$ rRNA was amplified using the primer set 28rd1a/28rd5b (Edgecombe and Giribet 2006). The COI fragment was amplified using the primer pair LCO1490/HCO2198 (Folmer et al. 1994). PCR reactions were performed using AmpliTaq DNA polymerase (Perkin-Elmer, Waltham, Massachusetts, USA). Thermal cycling was initiated with 2 min of denaturation at $94^{\circ} \mathrm{C}$ followed by 35 cycles of $30 \mathrm{~s}$ at $94^{\circ} \mathrm{C}, 1 \mathrm{~min}$ at $36-44^{\circ} \mathrm{C}$, and $1 \mathrm{~min}$ at $72^{\circ} \mathrm{C}$. After cycling, the reaction was completed with an extension phase at $72^{\circ} \mathrm{C}$ for $10 \mathrm{~min}$. The PCR products were visualized in a $1 \%$ agarose gel and purified through enzymatic reaction with ExoSAP-IT (USB Corporation, Cleveland, Ohio, USA). For both $28 \mathrm{~S}$ rRNA and COI, sequencing reaction products were analyzed using an ABI Prism 3730 Genetic Analyzer (Applied Biosystems, Foster City, California, USA). Chromatograms were edited and overlapping sequence fragments were assembled using Sequencher 4.8 (Gene Codes Corporation, Ann Arbor, Michigan, USA). Blast searches (Altschul et al. 1997), as implemented in the NCBI website (http://www.ncbi.nlm.nih.gov/), were conducted to check for putative contaminations. Sequences from the holotype (ZIHU 3819) are analysed in the present study (Table 1); those from one of the paratypes (ZIHU 3820) are also deposited at GenBank (accession numbers for 28S rRNA and COI, respectively, HQ856864 and HQ848629).

To assess the phylogenetic affinities of the new species, we included 14 species of palaeonemerteans, including two species of Carinoma, for which sequences were available in GenBank (Table 1). DNA sequence alignment was performed by MAFFT version 6 using the strategy G-INS-i (Katoh et al. 2005). The phoronid Phoronis vancouverensis Pixell, 1912 and the brachiopod Terebratalia transversa (Sowerby, 1846) were chosen as outgroups. Palaeonemerteans are often found as a basal group within Nemertea (Thollesson and Norenburg 2003), and the phyla Brachiopoda and Phoronida appear as the closest groups to nemerteans according to 
Table 1. List of species included in the phylogenetic analysis, with GenBank accession numbers.

\begin{tabular}{|c|c|c|}
\hline Species & $28 \mathrm{~S}$ rRNA & COI \\
\hline Callinera grandis Bergendal, 1903 & - & EU489491 ${ }^{\mathrm{a}}$ \\
\hline Carinina plecta Kajihara, 2006 & - & EU489493 ${ }^{\mathrm{a}}$ \\
\hline Carinina ochracea Sundberg et al. 2009 & - & EU489492 ${ }^{\mathrm{a}}$ \\
\hline Carinoma hamanako sp. nov. & HQ856863 ${ }^{b}$ & HQ848628 ${ }^{\mathrm{b}}$ \\
\hline Carinoma mutabile Griffin, 1898 & $\mathrm{AJ} 436887^{\mathrm{c}}$ & $\mathrm{AJ} 436942^{\mathrm{c}}$ \\
\hline Carinoma tremaphoros Thompson, 1900 & AJ $436888^{c}$ & $\mathrm{AJ} 436943^{\mathrm{c}}$ \\
\hline Cephalothrix filiformis (Johnston, 1828) & AJ $436890^{\mathrm{C}}$ & $\mathrm{AJ} 436944^{\mathrm{c}}$ \\
\hline Cephalothrix simula (Iwata, 1952) & AJ436891 & GU733830 ${ }^{\alpha}$ \\
\hline Cephalothrix spiralis Coe, 1930 & AJ436892 & $\mathrm{AJ} 436946^{\mathrm{c}}$ \\
\hline Hubrechtella dubia Bergendal, 1902 & $\mathrm{AJ} 436889^{\mathrm{c}}$ & EU489495 ${ }^{\mathrm{a}}$ \\
\hline Tubulanus annulatus (Montagu, 1804) & AY210473 & EU489497 ${ }^{\mathrm{a}}$ \\
\hline Tubulanus lutescens Cantell, 2001 & - & EU489498 ${ }^{a}$ \\
\hline Tubulanus punctatus (Takakura, 1898) & $\mathrm{AJ} 436893^{\mathrm{c}}$ & $\mathrm{AJ} 436947^{\mathrm{c}}$ \\
\hline Tubulanus rhabdotus Corrêa, 1954 & AJ436894 & AJ436948 \\
\hline Tubulanus sexlineatus (Griffin, 1898) & AJ $436895^{\mathrm{c}}$ & AJ436949c \\
\hline \multicolumn{3}{|l|}{ Outgroups } \\
\hline Phoronis vancouverensis Pixell, 1912 & AF342797f & EU484462 \\
\hline Terebratalia transversa (Sowerby, 1846) & $\mathrm{AF} 342802^{\mathrm{f}}$ & FJ196085 \\
\hline
\end{tabular}

Sources: aSundberg et al. (2009), b Andrade et al. (in press), "Thollesson and Norenburg (2003), ${ }^{\mathrm{d}}$ Chen et al.

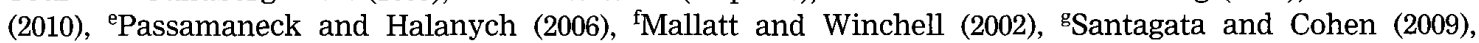
${ }^{\mathrm{h}} \mathrm{Fuchs}$ et al. (2009).

recent molecular phylogenies (Dunn et al. 2008). jMODELTEST 0.1.1 (Posada 2008) was used to choose the best-fit model of molecular evolution for our data set under the Akaike Information Criterion (Akaike 1974). This test suggested the general time-reversible model with a discrete Gamma distribution and rate heterogeneity $(\mathrm{GTR}+\mathrm{G}+\mathrm{I})$ as best fitting to the data for both the nuclear and mitochondrial genes. Maximum likelihood analyses were performed with RAxML verion 7.0.4 (Stamatakis 2006; Stamatakis et al. 2008) using the sequences obtained for $C$. hamanako, together with those of other palaeonemerteans and the outgroups from GenBank (Table 1). 28S rRNA and COI sequences were analysed independently; a concatenated dataset was also analysed. The search for the optimal maximum likelihood (ML) trees was performed in the cluster computing facility of the Faculty of Arts and Sciences, Harvard University. The ML tree search was conducted by performing 300 distinct runs using the default algorithm of the program for random trees (option -d) as a starting tree for each run. The final tree was determined by a comparison of likelihood scores under the GTR $+\mathrm{G}+\mathrm{I}$ model among suboptimal trees obtained per run. One thousand fast bootstrap replicates were conducted to evaluate nodal support. 


\section{Taxonomy}

Family Carinomidae Bergendal, 1900

Carinomidae Bergendal, 1900: 741; Bürger 1897-1907: 402, 414.

Statolitonemertidae Korotkevich, 1982: 17. Synonymized by Chernyshev (1999).

Remarks. Chernyshev (1999: 1275) ascribed the family name to Bürger (18971907), which, however, was published in six different parts, and the part containing the establishment of the family name Carinomidae was published in 1905. Therefore, Bergendal's (1900) usage of the name precedes that of Bürger (18971907). The formally correct spelling of the family name is Carinomatidae, given that the type genus Carinoma is taken to be neuter in gender (see Remarks for the genus below); however, the spelling Carinomidae is in prevailing use and Carinomatidae has never been used. Carinomidae should thus be retained under Article 29.5 of the International Code of Zoological Nomenclature (International Commission on Zoological Nomenclature 1999).

\section{Genus Carinoma Oudemans, 1885}

Carinoma Oudemans, 1885: 7. Type species: Valencinia armandi McIntosh, 1875, fixed by monotypy. Gender: neuter.

Remarks. Although Oudemans (1885) did not mention its etymology, the generic name Carinoma is apparently derived from Carinina, the palaeonemertean genus which was frequently referred to in the original description of Carinoma in conjunction with remarks on their mutual morphological similarity and/or dissimilarity. Because the suffix -oma is neuter in gender, the three specific epithets caraibica Stiasny-Wijnhoff, 1925, mutabilis Griffin, 1898, and patagonica Bürger, 1895, which were originally published and have widely been used in feminine form, should be caraibicum, mutabile, and patagonicum, respectively, when combined with Carinoma.

\section{Carinoma hamanako sp. nov.}

(Figs 1-5)

Material examined. Holotype: ZIHU 3819, serial transverse sections of anterior half of body, 19 slides. Paratypes: ZIHU 3820, serial transverse sections of anterior half of body, 10 slides; ZIHU 3821, serial transverse sections of anterior half of body, 8 slides.

Comparative material. Carinoma mutabile: ZIHU 3974, serial transverse sections of anterior fragment of body, sectioned at $9 \mu \mathrm{m}$ thickness, 20 slides, collected and identified by Svetlana A. Maslakova on 19 October 2009 from a mudflat in Charleston, Oregon, USA; ZIHU 3975, same data as 3974, serial transverse sections from tip of head to intestinal region of a complete specimen, sectioned at $10 \mu \mathrm{m}$ thickness, 20 slides. 


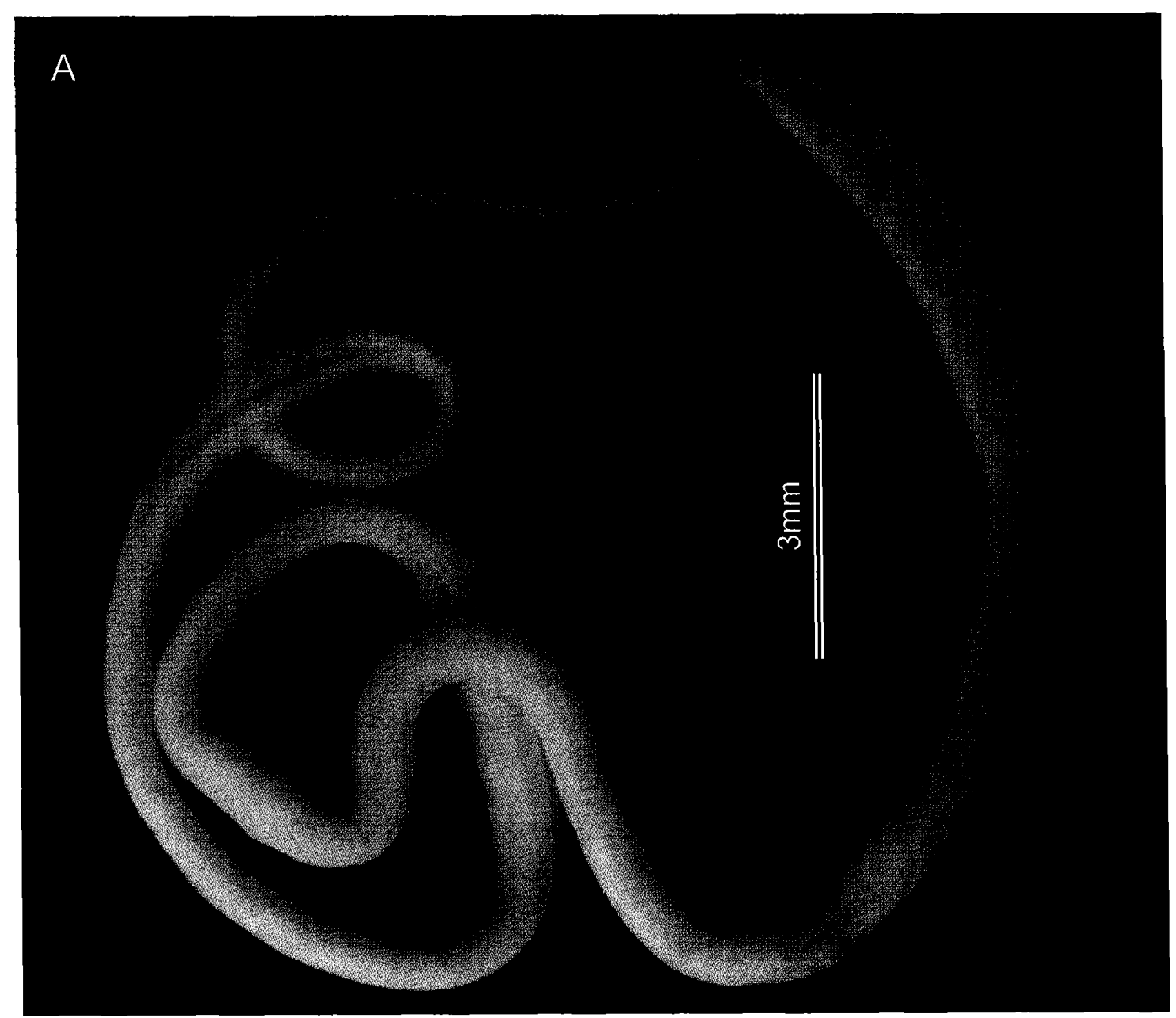

\section{B}

Fig. 1. Carinoma hamanako sp. nov., photographs in living state. A, Holotype, ZIHU 3819, general shape; B, paratype, ZIHU 3821, tail. 
Diagnosis. A Carinoma having 1) rhynchocoelic villar vessels terminating blindly posteriorly, 2) lateral rhynchocoel vessels posteriorly connected to the lateral vessels, 3) unbranched excretory canals, 4) the mid-dorsal nerve shifted downward into the body-wall longitudinal muscle layer in the posterior part of the body, and 5) lateral blood vessels that do not form a vascular plexus in the foregut region.

Description. External features. Body about $8 \mathrm{~cm}$ long and $1 \mathrm{~mm}$ wide (Fig. 1A). Head white, dorsoventrally flattened, with neither eyes nor cephalic furrows. Foregut region white, round in cross section. Intestinal region cream-white or yellowish-white, somewhat flattened dorsoventrally. Tail flattened, translucent, devoid of intestinal lateral diverticula (Fig. 1B).

Body wall. Epidermis without non-cellular inclusions. Epidermis of anterior body with intra-epithelial muscle fibre network (Fig. 2A). In brain region, thickness of epidermis/lateral body diameter $<1$. Dermis forming distinct zone between epidermis and body-wall circular muscle layer. Thickness of dermis less than half of epidermal height. Muscle processes (or radial muscles) extending from circular muscle layer into epidermis in cephalic region (Fig. 2B). Muscle layers consisting of outer circular and inner longitudinal muscle layers; anteriorly, three additional muscle layers present: 1) outer longitudinal muscle layer between dermis and outer circular muscle layer (Fig. 2A); 2) diagonal muscle layer beneath outer circular muscle layer (Fig. 2C); and 3) inner circular muscle layer interlaced with longitudinal muscle fibres and continuous with rhynchocoel wall, enormously thickened anterior to, but disappearing posterior to, foregut-intestine junction (Fig. 2D, E). Pre-cerebrally, dorsoventral and transverse muscles present, originating from within epidermis; some dorsoventral muscles piercing body-wall outer circular muscle layer, and running through cephalic blood lacunae; transverse muscles running along dorsal and ventral sides of body-wall outer circular muscle layer. Dorsal and ventral muscle crosses present between body wall circular muscle layers. Central (medial) muscle plate present between foregut and rhynchocoel only in oral region. Parenchyma barely distinguishable other than as membranes enclosing various body organ systems. Transverse muscle fibres present in mouth region (commencement of body-wall inner circular muscle layer).

Proboscis apparatus. Proboscis pore subterminal. Gland cells of rhynchodaeum completely absent in holotype, but sparsely present in one paratype (ZIHU 3820). Rhynchocoel composed of three regions. First region continuous with body-wall inner circular muscle layer, anteriorly consisting of circular muscle fi-

Fig. 2. Carinoma hamanako sp. nov., holotype, ZIHU 3819, photomicrographs of transverse sections. A, Brain region, showing body-wall musculature (arrowheads indicating intra-epithelial muscle fibres); B, pre-cerebral region, showing muscle processes from body-wall inner circular muscle layer penetrating dermis and extending to epidermis, indicated by arrowheads; C, foregut region, showing diagonal muscles beneath body-wall outer circular muscle layer, indicated by arrowheads; D-H, nephridial region, showing three different regions of rhynchocoel (white arrowhead indicating the first region, black the second, and gray the third). Abbreviations: DE, dermis; EP, epidermis; FG, foregut; IC, body-wall inner circular muscle layer; IL, body-wall inner longitudinal muscle layer; LD, intestinal lateral diverticulum; OC, body-wall outer circular muscle layer; OL, body-wall outer longitudinal muscle layer; RC, rhynchocoel. 

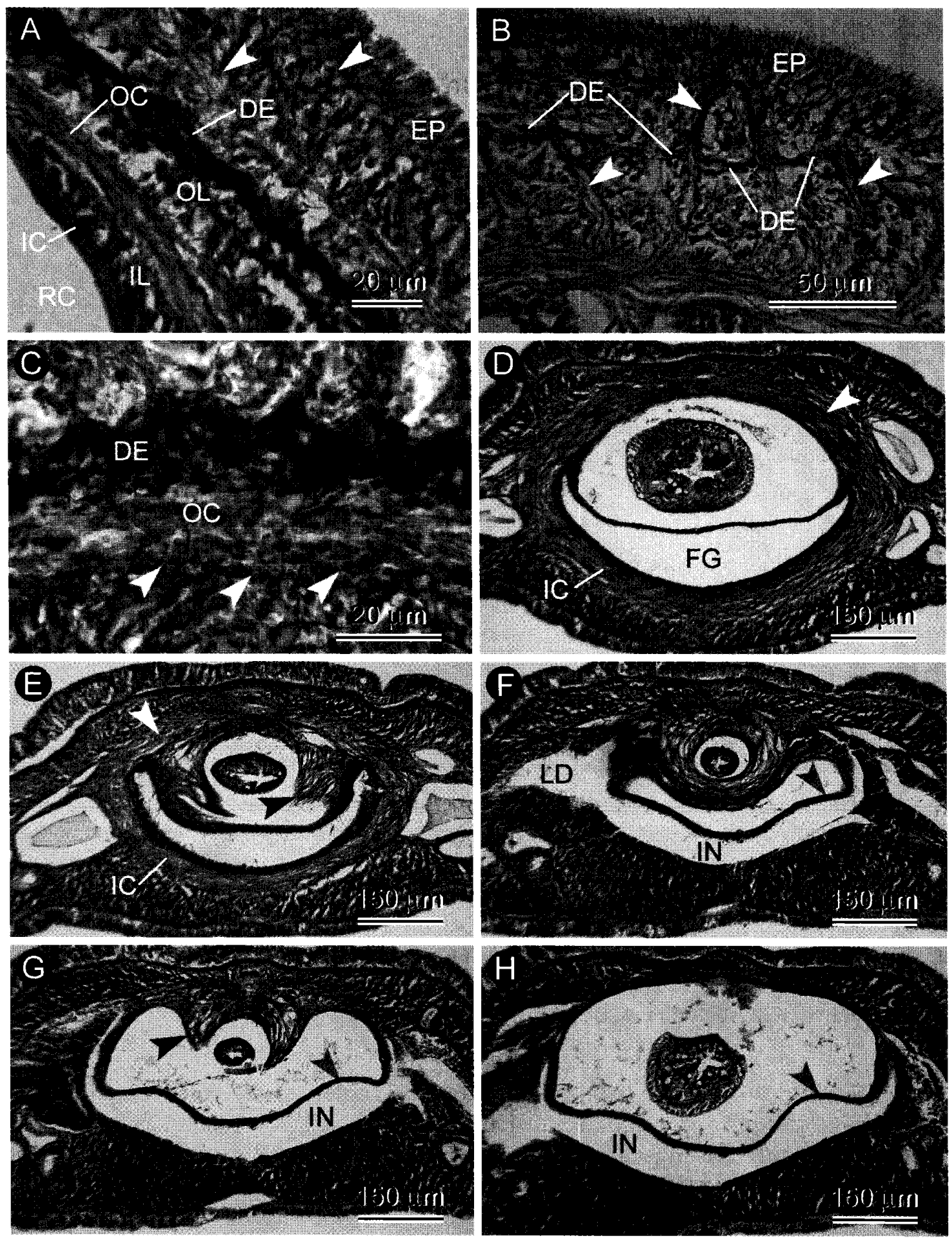

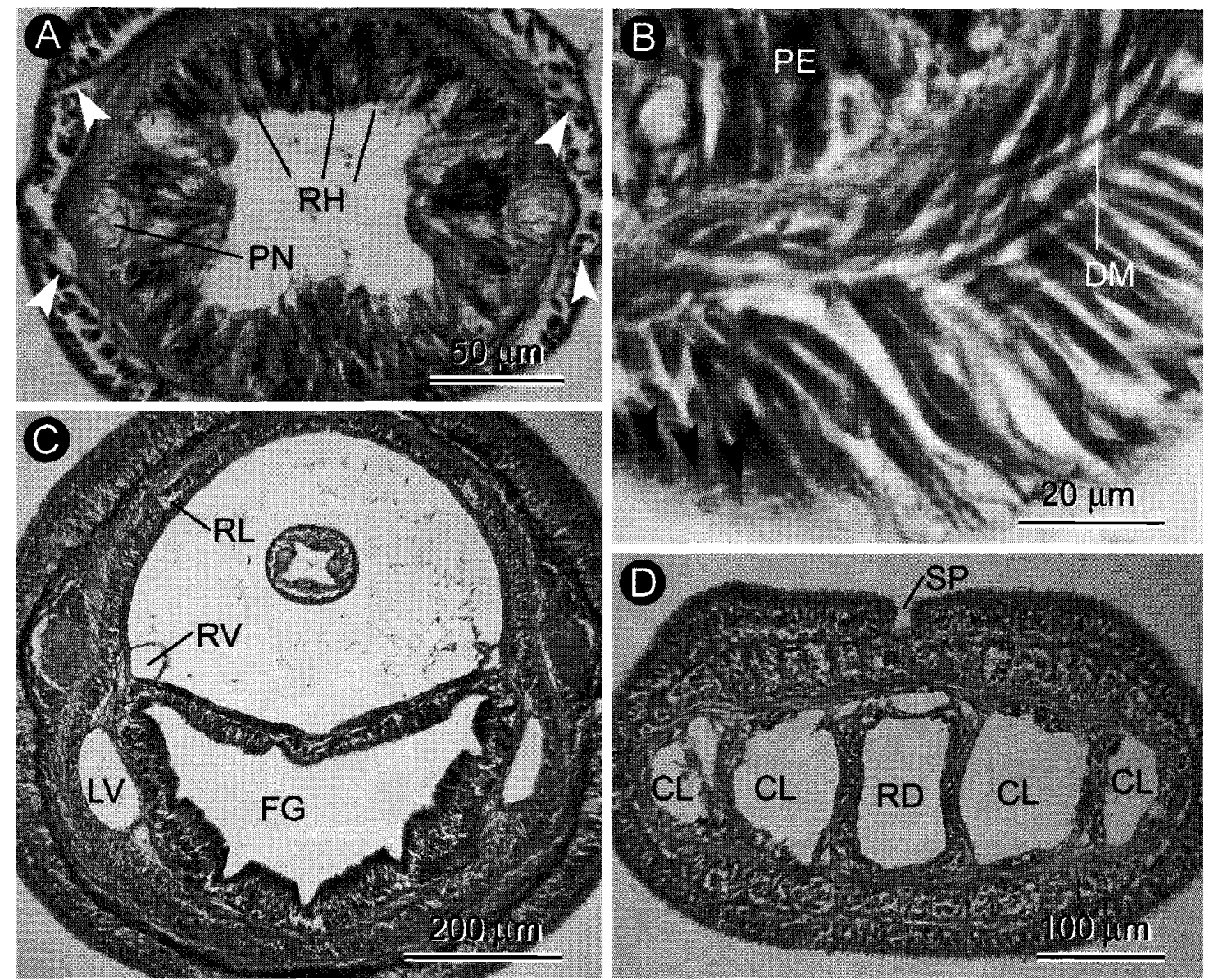

Fig. 3. Carinoma hamanako sp. nov., photomicrographs of transverse sections; A, B, D, holotype, ZIHU 3819; C, paratype, ZIHU 3820. A, Proboscis, showing non-overlapping muscle crosses, indicated by arrowheads; $\mathrm{B}$, proboscis, showing diagonal muscle layer and delicate inner circular muscles, indicated by arrowheads; C, foregut region; D, pre-cerebral region, showing four main channels of cephalic blood lacunae. Abbreviations: CL, cephalic blood lacuna; DM, diagonal muscles; FG, foregut; LV, lateral blood vessel; PE, proboscis epithelium; $\mathrm{PN}$, proboscis nerve; RD, rhynchodaeum; RH, rhabdoid; RL, lateral rhynchocoel blood lacuna; RV, rhynchocoelic villar vessel; SP, mid-dorsal sensory pit.

bres, thickened posteriorly in posterior stomach region, there consisting of interwoven longitudinal and circular muscle fibres (Fig. 2D, E). Second region short, consisting of circular muscles only, opening to dorsal wall of third region (Fig. $2 \mathrm{E}-\mathrm{G}$ ). Third region starting close to stomach-intestine junction, with thin wall composed of interwoven longitudinal and circular muscle fibres (Fig. 2F-H). Posterior end of rhynchocoel not included in all specimens examined, so rhynchocoel length unknown. Rhynchocoelic caecum not found. Proboscis insertion situated at cerebral ring. Proboscis showing no distinct antero-posterior histological differentiation; epithelium not developed into papillae; rhabdoids mostly found in dorsal side of epithelium (Fig. 3A). Proboscis musculature in everted state consisting of inner circular, longitudinal, diagonal, and outer circular muscle layers (Fig. 3B); two muscle crosses of non-overlapping type (cf. Chernyshev 2010) present between 
diagonal layer and outer circular muscle layer (Fig. 3A). Proboscis with two nerves (Fig. 3A); peripheral neural sheath indistinct. Proboscis armature absent. Proboscis not used for locomotion.

Alimentary system. Mouth located just behind brain. Oesophagus absent. Stomach histologically differentiated into anterior basophilic (Fig. 3C) and posterior acidophilic regions (Fig. 2D). Intestinal caecum absent. Intestinal diverticula (Fig. 2F) simple, unbranched pouches.

Circulatory system. Cephalic vasculature forming blood lacunae in front of cerebral ganglia, consisting of four main channels connected by dorsal and ventral anastomoses (Fig. 3D). Pair of rhynchocoelic villar vessels present (Fig. 3C), terminating blindly in anterior foregut region. Pair of lateral rhynchocoel blood lacuna present, originating from lateral vessels anteriorly, then running dorsolaterally just outside rhynchocoel wall (Fig. 3C), and posteriorly rejoining lateral vessels at foregut-intestine junction; lateral rhynchocoel blood lacuna becoming very narrow before rejoining lateral vessel (Fig. 4A-H). Lateral blood vessel (=lateral lacuna) outside body-wall inner circular muscle layer (Fig. 3C). Mid-dorsal vessel absent. Extra vascular pouches absent. Vascular plexus absent in foregut region.

Nervous system. Cerebral ganglia and anterior part of lateral nerve cords external to body-wall outer circular muscle layer, posterior parts of lateral nerve cords found among inner longitudinal muscle fibres. Dorsal cerebral ganglia with one commissure. Outer neurilemma of cerebral ganglion absent, but inner neurilemma present. No statocysts in brain tissue. Large nerves absent in head region. Mid-dorsal nerve and mid-ventral nerve situated outside body-wall outer circular muscle layer anteriorly, but embedded in longitudinal muscle layer posteriorly. Posterior junction of lateral nerve cords unknown. Pair of neurochord cells present posterior to dorsal cerebral ganglion on each side (Fig. 5A). Neurochords present in lateral nerve cords (Fig. 4A). Myofibrillae absent in lateral nerve cords. Buccal nerves absent.

Excretory system. Excretory canal situated below lateral blood vessel on each side (Fig. 4A), extending backward from posterior foregut region to anterior intestinal region, turning anteriorly, then bending slightly posterodorsad to lead to excretory pore near foregut-intestine junction (Fig. 5B). Excretory canal unbranched, situated outside body-wall inner circular muscle layer. Nephridial gland inconspicuous. Glandular components not found in excretory tubules.

Reproductive system. Sexes presumably separate; among examined specimens, only holotype (a mature male) including posterior gonadal region. Single testis alternating with intestinal diverticula (Fig. 5C). Gonoduct dorsolateral. Reproductive strategy unknown.

Sensory organs. Apical organ absent. Typical basophilic cephalic glands extending to level of brain, but not behind it, situated between body-wall inner circular muscle layer and connective tissue basement membrane, opening through numerous independent ducts. Cerebral organ absent. Side organs (=lateral sensory organs) absent. Ten mid-dorsal sensory pits in head region present in all specimens examined (Figs 3D, 5D).

Etymology. The specific epithet, a noun in apposition, is the Japanese name for Lake Hamana, the type locality of the new species.

Remarks. The anatomical features of the present species, including intra-epithelial muscle fibres in the epidermis of the anterior body, the rhynchocoel wall 

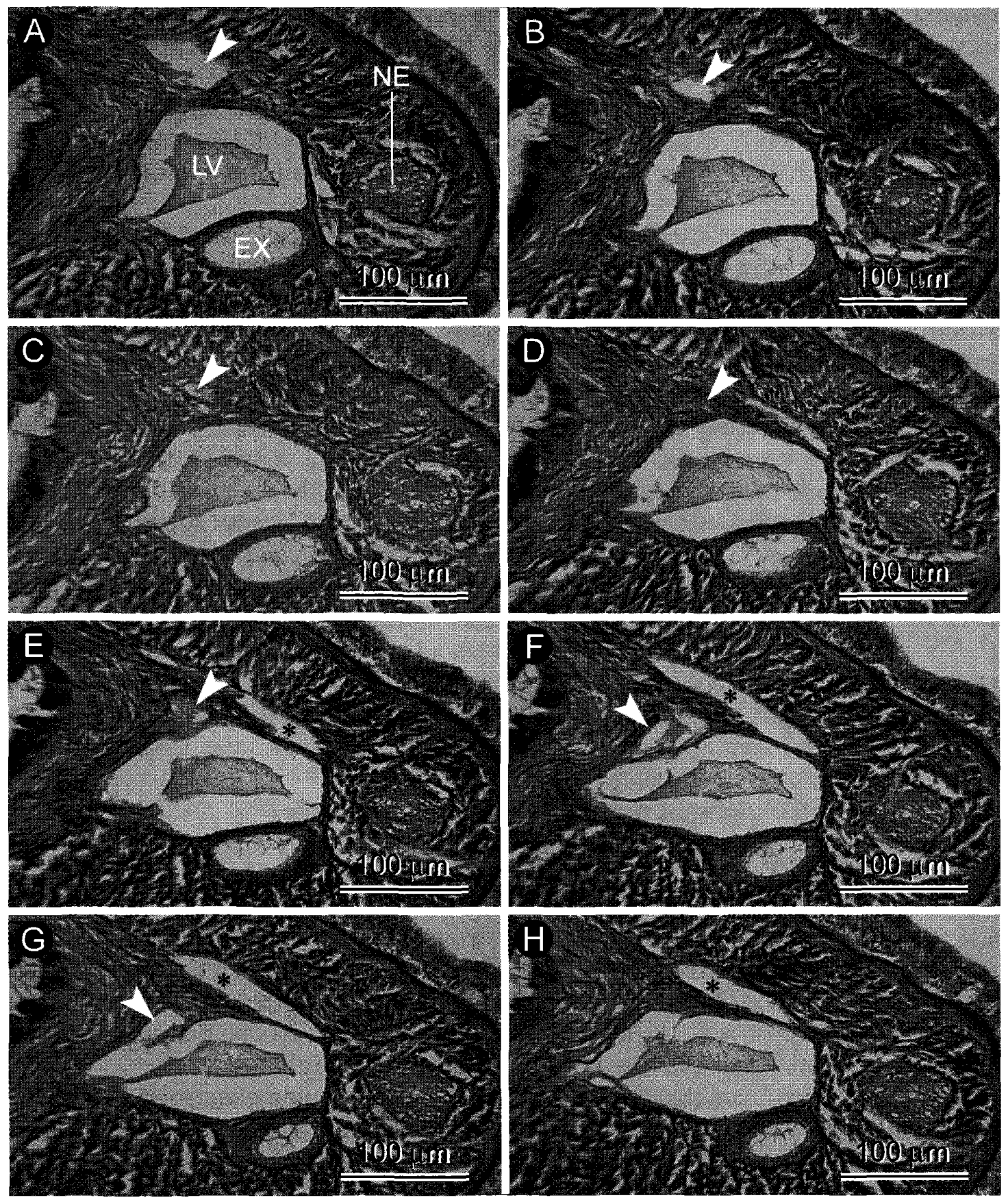

Fig. 4. Carinoma hamanako sp. nov., holotype, ZIHU 3819, photomicrographs of transverse sections (A-H, anterior to posterior), showing lateral rhynchocoel blood lacuna (indicated by arrowheads) rejoining lateral vessel; anterior-most gonadal sac indicated by asterisk. Abbreviations: EX, excretory canal; LV, lateral blood vessel; NE, neurochord.

being partially composed of interwoven longitudinal and circular fibres, the blood system with six post-cerebral vessels in the foregut region, and the absence of statocysts, agree well with the diagnoses of Carinoma given by Gibson (1979) and Chernyshev (1999). This genus currently includes eight species: C. armandi (McIn- 

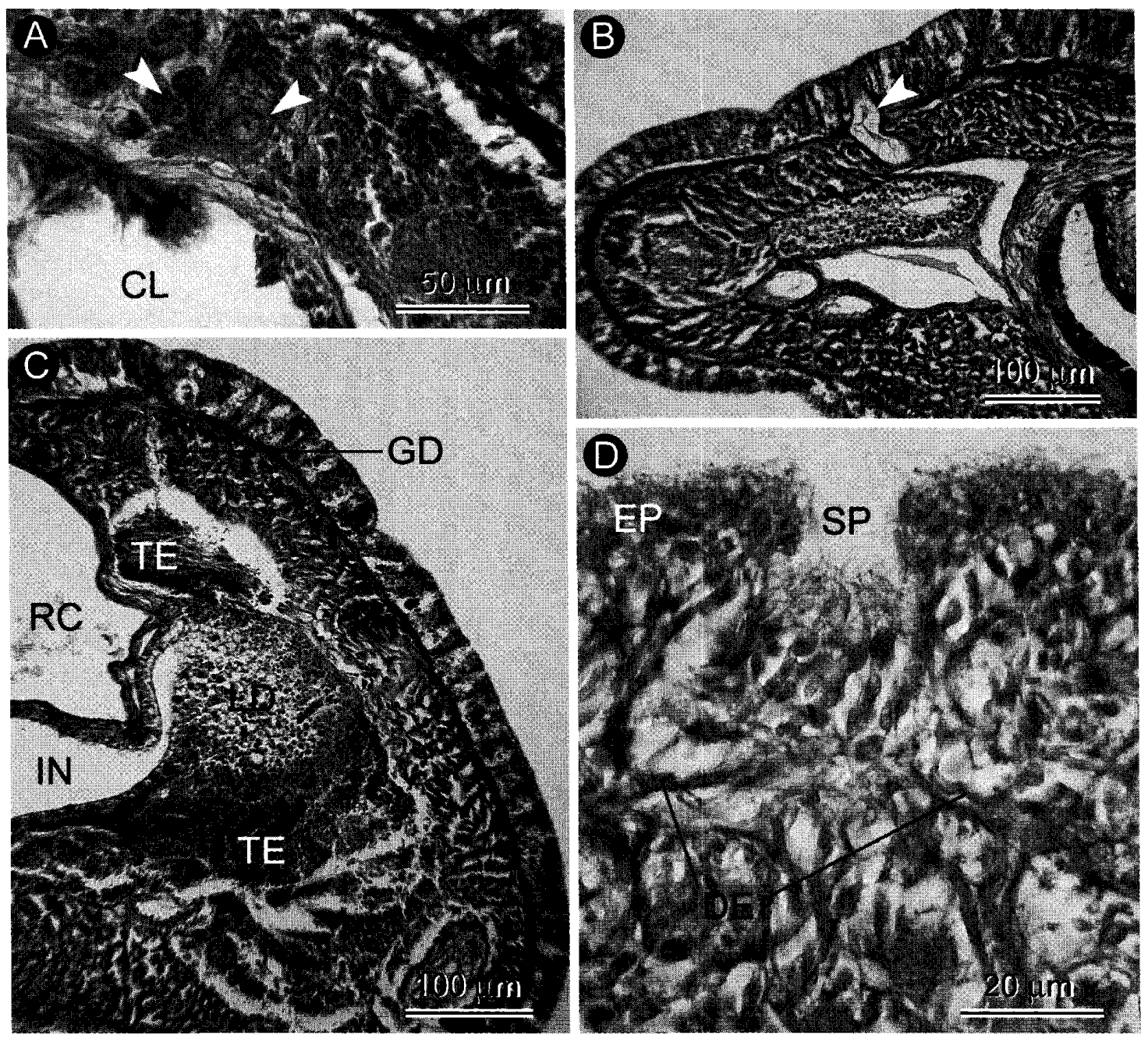

Fig. 5. Carinoma hamanako sp. nov., holotype, ZIHU 3819, photomicrographs of transverse sections. A, Pair of neurochord cells, indicated by arrowheads; B, excretory pore, indicated by arrowhead; $\mathrm{C}$, intestinal region, showing arrangement of testis; $\mathrm{D}$, pre-cerebral region, showing mid-dorsal sensory pit. Abbreviations: CL, cephalic blood lacuna; DE, dermis; EP, epidermis; GD, gonoduct; IN, intestine; LD, intestinal lateral diverticulum; RC, rhynchocoel; SP, mid-dorsal sensory pit; TE, testis.

tosh, 1875) from the UK (McIntosh 1875; Bergendal 1902, 1903a, b); C. caraibicum from Curaçao, in the Caribbean Sea (Stiasny-Wijnhoff 1925); C. mutabile from the Pacific coast of the USA (Griffin 1898; Coe 1901, 1904, 1905, 1940, Corrêa 1964; Okazaki et al. 1988; Hochberg and Lunianski 1998; Thollesson and Norenburg 2003); C. patagonicum from Punta Arenas, Chile (Bürger 1895a); C. patriciae Gibson, 1979 from Magnetic Island, Australia (Gibson 1979); C. renieri Senz, 2000 from the Arabian (or Persian) Gulf (Senz 2000); C. tremaphoros Thompson, 1900 from the Atlantic coast of the USA (Thompson 1900; Sumner et al. 1913; Coe 1943, 1951; McCaul 1963; Turbeville and Ruppert 1983; Thollesson and Norenburg 2003; Maslakova et al. 2004a, b); and C. uschakovi Chernyshev, 1999 from the White Sea and the Barents Sea (Chernyshev 1999). The new species differs from its congeners by the com- 


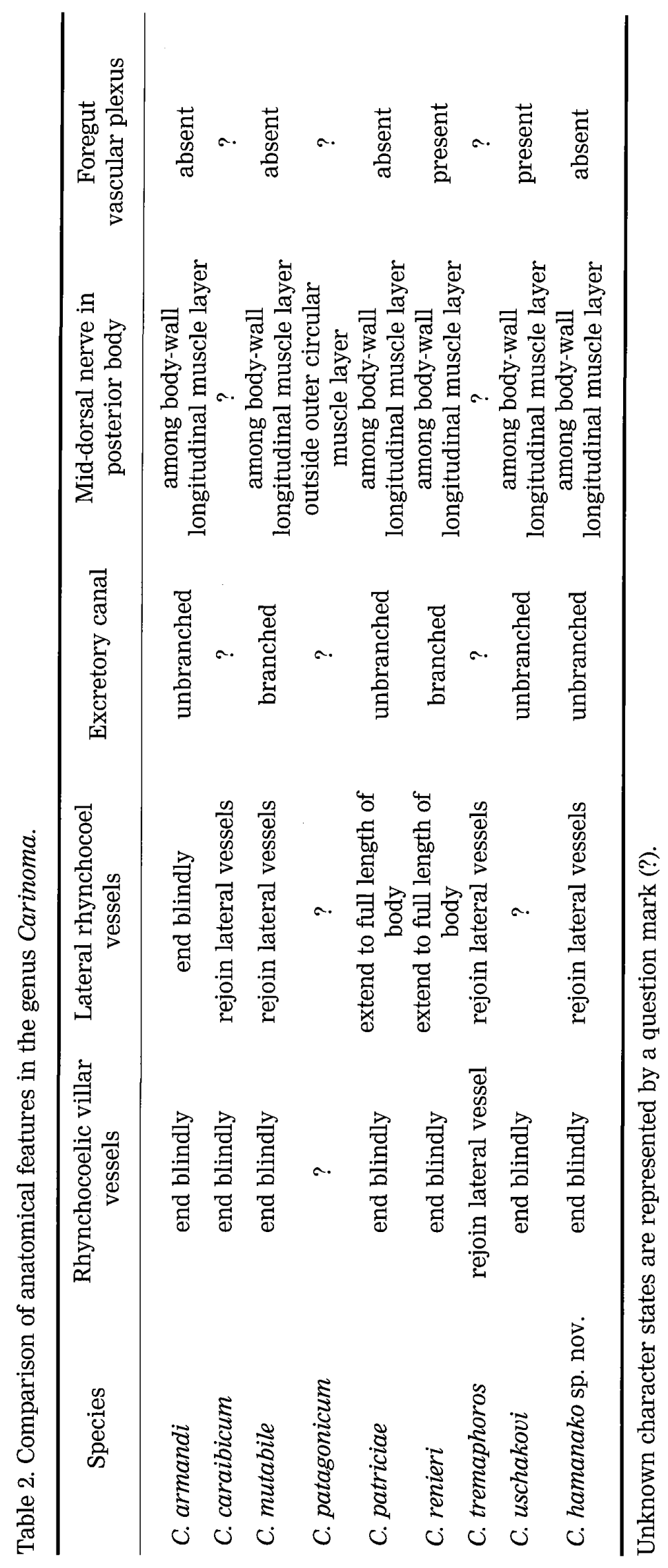




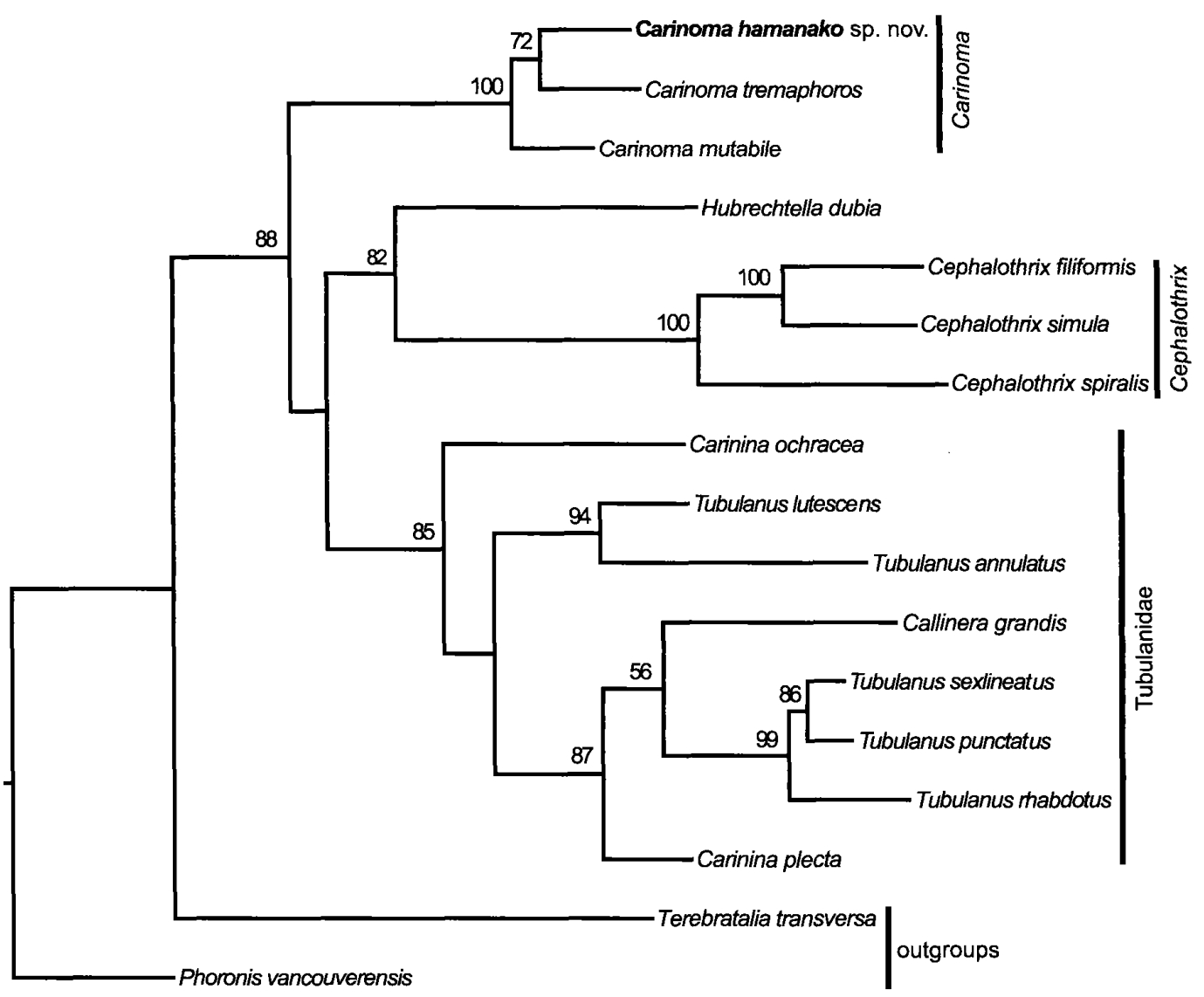

Fig. 6. Phylogenetic tree resulting from maximum likelihood analysis of combined 28S rRNA and COI ( $\ln \mathrm{L}=-14170.39$ ). Numbers on nodes indicate bootstrap support values $\geq 50 \%$.

bination of characters summarised in Table 2 and formalised above in the specific diagnosis.

\section{Molecular Phylogeny}

The $28 \mathrm{~S}$ rRNA dataset comprised 13 sequences, which resulted in a multiple sequence alignment of $1,260 \mathrm{bp}$. Uncorrected $p$-distances between the $28 \mathrm{~S}$ rRNA sequences of $C$. hamanako/C. mutabile, $C$. hamanako/C. tremaphoros, and $C$. mutabile/C. tremaphoros were $4.8 \%, 5.1 \%$, and $6.0 \%$, respectively. The resulting likelihood tree ( $\ln \mathrm{L}=-8066.08$ ) showed monophyly of Carinoma with $100 \%$ bootstrap frequency (BF hereafter) (data not shown). Carinoma hamanako formed a clade with $C$. tremaphoros, with $C$. mutabile as their sister group. The COI dataset comprised 17 sequences and the software package MAFFT yielded a $679 \mathrm{bp}$ alignment. Its resulting likelihood tree ( $\ln \mathrm{L}=-5609.79$ ) presented a topology similar to that of $28 \mathrm{~S}$ rRNA, with minor differences (data not shown). Uncorrected $p$-distances between the COI sequences of $C$. hamanako/C. mutabile, C. hamanako/C. tremaphoros, and C. mutabile/C. tremaphoros were $17.2 \%, 15.0 \%$, and $15.2 \%$, respectively. The maximum likelihood analysis for the concatenated $28 \mathrm{~S}$ rRNA and COI 
sequences gave a tree of $\ln \mathrm{L}=-14170.39$, showing monophyly of Carinoma with $100 \%$ BF (Fig. 6). It also demonstrated the monophyly of Cephalothrix, with nodal support of $100 \%$ BF. Hubrechtella dubia Bergendal, 1902 appeared as the sister taxon to Cephalothrix with high nodal support $(82 \% \mathrm{BF})$. Their joint clade is the sister group of a clade containing the species of Tubulanidae included in the analysis.

Our phylogenetic analysis supports the previous notion that Carinoma is a group distinct from other palaeonemerteans (e.g., Bürger 1895b; Bergendal 1900; Friedrich 1935; Hylbom 1956), and also confirms the placement of $C$. hamanako in the genus Carinoma. Despite the relative geographical distances, $C$. hamanako from the Western Pacific turned out to be more closely related to the Western Atlantic $C$. tremaphoros than to the Eastern Pacific C. mutabile. A comprehensive biogeographic and phylogeographic study of the species of Carinoma will likely shed light on the evolution and distribution of these nemerteans.

\section{Acknowledgements}

We are indebted to Naoki Mizuno of the Fisheries Laboratory, Graduate School of Agricultural and Life Sciences, the University of Tokyo, for help in collecting specimens in the field; to Junko Sato for help in preparing histological sections; and to Svetlana A. Maslakova for supplying specimens of Carinoma mutabile for comparison. We are thankful to Gonzalo Giribet for comments on an earlier version of this manuscript and for sponsoring the molecular sequence data obtained in his laboratory. The computations in this paper were run on the Odyssey Cluster, supported by the Faculty of Arts and Sciences, Science Division Research Computing Group at Harvard University. This study was partially supported by a Narishige Zoological Science Award to HK (FY 2009). This work is part of NemPhyl, an international project to reconstruct the nemertean phylogeny, led by Professors Per Sundberg, University of Gothenburg, and Gonzalo Giribet, Harvard University.

\section{References}

Akaike, H. 1974. A new look at the statistical model identification. IEEE Transactions on Automatic Control 19: 716-723.

Altschul, S. F., Madden, T. L., Schäffer, A. A., Zhang, J.-H., Zhang, Z., Miller, W. and Lipman, D. J. 1997. Gapped Blast and Psi-blast: a new generation of protein database search programs. Nucleic Acids Research 25: 3389-3402.

Andrade, S. C .S., Strand, M., Schwartz, M., Chen, H.-X., Kajihara, H., von Döhren, J., Sun, S.C., Junoy, J., Thiel, M., Norenburg, J. L., Turbeville, J. M., Giribet, G. and Sundberg, P. In press. Disentangling ribbon worm relationships: multi-locus analysis supports traditional classification of the phylum Nemertea. Cladistics.

Bergendal, D. 1900. Bör Ordningen Palaeonemertini Hubrecht uppdelas i ivänne Ordningar Protonemertini och Mesonemertini? Öfversigt af Kongliga Vetenskaps-Akademiens Förhandlingar 57: 721-742.

Bergendal, D. 1902. Einige Bemerkungen über Carinoma armandi Oudemans (sp. McInt.). Öfversigt af Kongliga Vetenskaps-Akademiens Förhandlingar 59: 13-18.

Bergendal, D. 1903a. Über "Sinnesgrübchen" im Epithel des Vorderkopfes bei Carinoma ar- 
mandi sp. McInt. (Oudemans) nebst einigen systematischen Bemerkungen über die Arten dieser Gattung. Zoologischer Anzeiger 26: 608-619.

Bergendal, D. 1903b. Studien über Nemertinen. III. Beobachtungen über den Bau von Carinoma Oudemans nebst Beiträgen zur Systematik der Nemertinen. Lunds Universitets Årsskrift 39: 1-86.

Bürger, O. 1895a. Beiträge zur Anatomie, Systematik und geographischen Verbreitung der Nemertinen. Zeitschrift für Wissenschaftliche Zoologie 61: 16-37.

Bürger, O. 1895b. Die Nemertinen des Golfes von Neapel und der angrenzenden MeeresAbschnitte. Fauna und Flora des Golfes von Neapel 22: 1-743.

Bürger, O. 1897-1907. Nemertini (Schnurwürmer). Pp. 1-542. In: Bronn, H. G. (Ed.) Klassen und Ordnungen des Tier-Reichs, Vol. 4, Supplement. C. F. Winter, Leipzig. [Pp. 1-176 in 1897 ; pp. $177-240$ in 1898; pp. 241-288 in 1899; pp. 289-384 in 1903; pp. 385-480 in 1905; pp. 481-542 in 1907]

Chen, H.-X., Strand, M., Norenburg, J. L., Sun, S.-C., Kajihara, H., Chernyshev, A. V., Maslakova, S. A. and Sundberg, P. 2010. Statistical parsimony networks and species assemblages in cephalotrichid nemerteans (Nemertea). PLoS ONE 5 (9): e12885.

Chernyshev, A. V. 1999. Nemertines of the family Carinomidae (Nemertea, Anopla). 1. Description of Carinoma uschakovi sp. n. and Statolitonemertes sachalinica Korotkevitsch. Zoologicheskii Zhurnal 78: 1275-1283. [In Russian with English abstract]

Chernyshev, A. V. 2010. Confocal laser scanning microscopy analysis of the phalloidinlabelled musculature in nemerteans. Journal of Natural History 44: 2287-2302.

Coe, W. R. 1901. Papers from the Harriman Alaska Expedition. XX. The nemerteans. Proceedings of the Washington Academy of Sciences 3: 1-110, pls I-XIII.

Coe, W. R. 1904. Nemerteans of the Pacific Coast of North America. Harriman Alaska Series 11: $111-220$.

Coe, W. R. 1905. Nemerteans of the West and Northwest Coasts of America. Bulletin of the Museum of Comparative Zoölogy at Harvard College 47: 1-318.

Coe, W. R. 1940. Revision of the nemertean fauna of the Pacific Coasts of North, Central, and northern South America. Allan Hancock Pacific Expeditions 2: 247-322.

Coe, W. R. 1943. Biology of the nemerteans of the Atlantic Coast of North America. Transactions of the Connecticut Academy of Arts and Sciences 35: 129-328.

Coe, W. R. 1951. The nemertean faunas of the Gulf of Mexico and of southern Florida. Bulletin of Marine Science of the Gulf and Caribbean 1: 149-186.

Corrêa, D. D. 1964. Nemerteans from California and Oregon. Proceedings of the California Academy of Sciences 31: 515-558.

Dunn, C. W., Hejnol, A., Matus, D. Q., Pang, K., Browne, W. E., Smith, S. A., Seaver, E., Rouse, G. W., Obst, M., Edgecombe, G. D., Sørensen, M. V., Haddock, S. H., Schmidt-Rhaesa, A., Okusu, A., Kristensen, R. M., Wheeler, W. C., Martindale, M. Q. and Giribet, G. 2008. Broad phylogenomic sampling improves resolution of the animal tree of life. Nature 452: 745-749.

Edgecombe, G. D. and Giribet, G. 2006. A century later-a total evidence re-evaluation of the phylogeny of scutigeromorph centipedes (Myriapoda: Chilopoda). Invertebrate Systematics 20: 503-525.

Folmer, O., Black, M., Hoeh, W., Lutz, R. and Vrijenhoek, R. C. 1994. DNA primers for amplification of mitochondrial cytochrome $c$ oxidase subunit I from diverse metazoan invertebrates. Molecular Marine Biology and Biotechnology 3: 294-299.

Friedrich, H. 1935. Studien zur Morphologie, Systematik und Ökologie der Nemertinen der Kieler Bucht. Archiv für Naturgeschichte 4: 293-375. 
Fuchs, J., Obst, M. and Sundberg, P. 2009. The first comprehensive molecular phylogeny of Bryozoa (Ectoprocta) based on combined analyses of nuclear and mitochondrial genes. Molecular Phylogenetics and Evolution 52: 225-233.

Gibson, R. 1979. Nemerteans of the Great Barrier Reef. 1. Anopla Palaeonemertea. Zoological Journal of the Linnean Society 65: 305-337.

Gibson, R. 1994. Nemerteans. Field Studies Council, Shrewsbury, vii + 224 pp.

Gibson, R. 1995. Nemertean genera and species of the world: an annotated checklist of original names and description citations, synonyms, current taxonomic status, habitats and recorded zoogeographic distribution. Journal of Natural History 29: 271-562.

Griffin, B. B. 1898. Description of some marine nemerteans of Puget Sound and Alaska. Annals of the New York Academy of Sciences 11: 193-217.

Hochberg, F. G. and Lunianski, D. N. 1998. Nemertean collections at the Santa Barbara Museum of Natural History: type specimens and vouchers for Wesley R. Coe's 1940 publication. Hydrobiologia 365: 291-300.

Hylbom, R. 1956. Studies on palaeonemerteans of the Gullmar Fiord area (West Coast of Sweden). Arkiv för Zoologi 10: 539-582.

International Commission on Zoological Nomenclature. 1999. International Code of Zoological Nomenclature, Fourth Edition. International Trust for Zoological Nomenclature, London, xxix $+306 \mathrm{pp}$.

Iwata, F. 1951. Nemerteans in the vicinity of Onomichi. Journal of the Faculty of Science, Hokkaido University, Series 6, Zoology 10: 135-138.

Iwata, F. 1952. Nemertini from the coasts of Kyusyu. Journal of the Faculty of Science, Hokkaido University, Series 6, Zoology 11: 126-148.

Iwata, F. 1954a. The fauna of Akkeshi Bay. XX. Nemertini in Hokkaido. Journal of the Faculty of Science, Hokkaido University, Series 6, Zoology 12: 1-39.

Iwata, F. 1954b. Some nemerteans from the coasts of the Kii Peninsula. Publications of the Seto marine Biological Laboratory 4: 33-42.

Iwata, F. 1957. Nemerteans from Sagami Bay. Publications from the Akkeshi Marine Biological Station 7: 1-31.

Kajihara, H. 2006. Four palaeonemerteans (Nemertea: Anopla) from a tidal flat in middle Honshu, Japan. Zootaxa 1163: 1-47.

Kajihara, H. 2007. A taxonomic catalogue of Japanese nemerteans (phylum Nemertea). Zoological Science 27: 287-326.

Kajihara, H., Chernyshev, A. V., Sun, S.-C., Sundberg, P. and Crandall, F. B. 2008. Checklist of nemertean genera and species published between 1995 and 2007. Species Diversity 13: 245-274.

Katoh, K., Kuma, K., Toh, H. and Miyata, T. 2005. MAFFT version 5: improvement in accuracy of multiple sequence alignment. Nucleic Acids Research 33: 511-518.

Korotkevich, V. S. 1982. [New and rare nemerteans (Nemertini) from the southern shelf of the Sakhalin Island]. Issledovaniya Faunui Morei 37: 12-26. [In Russian with English abstract]

Mallatt, J. and Winchell, C. J. 2002. Testing the new animal phylogeny: first use of combined large-subunit and small-subunit rRNA gene sequences to classify the protostomes. Molecular Biology and Evolution 19: 289-301.

Maslakova, S. A., Martindale, M. Q. and Norenburg, J. L. 2004a. Fundamental properties of the spiralian developmental program are displayed by the basal nemertean Carinoma tremaphoros (Palaeonemertea, Nemertea). Developmental Biology 267: 342-360.

Maslakova, S. A., Martindale, M. Q. and Norenburg, J. L. 2004b. Vestigial prototroch in a 
basal nemertean, Carinoma tremaphoros (Nemertea; Paleonemertea). Evolution and Development 6: 219-226.

McCaul, W. E. 1963. Rhynchocoela: nemerteans from marine and estuarine waters of Virginia. Journal of the Elisha Mitchell Scientific Society 79: 111-124.

McIntosh, W. C. 1875. On Valencinia armandi, a new nemertean. Transactions of the Linnean Society of London 1: 73-81.

Okazaki, R. K., Snyder, M. J. and Chang, E. S. 1988. Ecdysteroids in nemerteans: presence and physiological role. Hydrobiologia 156: 153-160.

Oudemans, A. C. 1885. The circulatory and nephridial apparatus of the Nemertea. Quarterly Journal of Microscopical Science 25 (suppl.): 1-80.

Passamaneck, Y. and Halanych, K. M. 2006. Lophotrochozoan phylogeny assessed with LSU and SSU data: evidence of lophophorate polyphyly. Molecular Phylogenetics and Evolution 40: 20-28.

Posada, D. 2008. jModelTest: phylogenetic model averaging. Molecular Biology and Evolution 25: $1253-1256$.

Santagata, S. and Cohen, B. L. 2009. Phoronid phylogenetics (Brachiopoda; Phoronata): evidence from morphological cladistics, small and large subunit rDNA sequences, and mitochondrial cox1. Zoological Journal of the Linnean Society 157: 34-50.

Senz, W. 1997. Morphologie und klassifikatorische Position einiger anopler Nemertinen (Nemertini: Anopla). Annalen des Naturhistorischen Museums in Wien 99B: 423-496.

Senz, W. 2000. Neue Nemertinen aus dem Golf von Arabien. 1. Palaeonemertini. Annalen des Naturhistorischen Museums in Wien 102B: 321-373.

Stamatakis, A. 2006. RAxML-VI-HPC: maximum likelihood-based phylogenetic analyses with thousands of taxa and mixed models. Bioinformatics 22: 2688-2690.

Stamatakis, A., Hoover, P. and Rougemont, J. 2008. A fast bootstrapping algorithm for the RAxML web-servers. Systematic Biology 57: 758-771.

Stiasny-Wijnhoff, G. 1925. On a collection of nemerteans from Curaçao. Bijdragen tot de Kennis der Fauna van Curaçao 24: 97-120.

Sumner, F. B., Osburn, R. C. and Cole, L. J. 1913. A biological survey of the waters of Woods Hole and vicinity. Section III. A catalogue of the marine fauna of Woods Hole and vicinity. Bulletin of the Bureau of Fisheries 31: 549-794.

Sundberg, P., Chernyshev, A. V., Kajihara, H., Kånneby, T. and Strand, M. 2009. Charactermatrix based descriptions of two new nemertean (Nemertea) species. Zoological Journal of the Linnean Society 157: 264-294.

Takakura, U. 1898. [Classification of the nemerteans (Nemertini) of the vicinity of Misaki]. Zoological Magazine, Tokyo 10: 38-44, 116-120, 184-187, 331-337, 424-429. [In Japanese]

Takakura, U. 1922. [On a new genus of nemertean from Japan]. Zoological Magazine, Tokyo 34: 419-422. [In Japanese]

Thollesson, M. and Norenburg, J. L. 2003. Ribbon worm relationships: a phylogeny of the phylum Nemertea. Proceedings of the Royal Society B 270: 407-415.

Thompson, C. B. 1900. Carinoma tremaphoros, a new mesonemertean species. Zoologischer Anzeiger 23: 627-630.

Turbeville, J. M. and Ruppert, E. E. 1983. Epidermal muscles and peristaltic burrowing in Carinoma tremaphoros (Nemertini): correlates of effective burrowing without segmentation. Zoomorphology 103: 103-120.

Yamaoka, T. 1940. The fauna of Akkeshi Bay. IX. Nemertini. Journal of the Faculty of Science, Hokkaido Imperial University, Series 6, Zoology 7: 205-263. 